\title{
Effects of the Ultra-Short-Acting Beta-Blocker Esmolol Infusion on Cardiovascular Parameters and Quality of Postoperative Recovery in Patients Scheduled for Elective Plastic Surgery
}

\author{
Dragana Lončar-Stojiljković1, 2,3
}

\section{Abstract}

Background/Aim: Esmolol is an ultra-short-acting, easily titratable $\beta$-adrenergic receptor antagonist used for urgent treatment of hypertension and tachycardia in non-surgical and surgical settings. Aim of this clinical study was to investigate its cardiovascular effects and quality of the emergence from anaesthesia in patients scheduled for elective plastic surgery under general balanced anaesthesia.

Methods: A total of 30 ASA I/II patients were randomised in two groups of similar demographic characteristics and baseline values of cardiovascular parameters. Esmolol group received esmolol dissolved in glucose $5 \%$ as an intravenous infusion, $0.3 \mathrm{mg} / \mathrm{kg} / \mathrm{min}$ during the first $5 \mathrm{~min}$ and at a rate of $0.1 \mathrm{mg} / \mathrm{kg} /$ min thereafter. Control patients received the solvent only, at the same rate and volume. General balanced anaesthesia was induced with thiopentone sodium and fentanyl and maintained with nitrous oxide and oxygen. Neuromuscular relaxation was assured with pancuronium bromide and was antagonised at the end of operation with atropine and neostigmine. Systolic and diastolic blood pressure and heart rate were registered at all critical phases: (1) immediately prior to the induction (baseline value), (2) induction to anaesthesia, (3) tracheal intubation, (4) first skin incision, (5) surgical manipulation with organs, (6) suture of the surgical wound and (7) tracheal extubation. Drug consumption and quality of postoperative recovery were monitored.

Results: In most of the critical phases of anaesthesia and operation, patients from the Esmolol group had significantly lower values of cardiovascular parameters than the patients from the Control group. Esmolol-treated patients needed less fentanyl, droperidol and pancuronium and had faster and smoother emergence from anaesthesia than the control patients.

Conclusion: Esmolol improved haemodynamics and post-anaesthesia recovery in patients undergoing elective plastic surgery under general balanced anaesthesia.

Key words: Esmolol; Beta-blockers; Anaesthesia; Plastic surgery; Cardiovascular parameters.
(1) Faculty of Medicine, University of Banja Luka, Banja Luka, the Republic of Srpska, Bosnia and Herzegovina.

(2) Dedinje Cardiovascular Institute, Belgrade, Serbia

(3) Military Medical Academy, Belgrade, Serbia.
Correspondence:

DRAGANA

LONČAR-STOJILJKOVIĆ

E: dragana.loncar-stojiljkovic@ med.unibl.org

\section{ARTICLE INFO}

Received: 10 September 2021 Revision received: 29 September 2021 Accepted: 30 September 2021

\section{Introduction}

Laryngoscopy, tracheal intubation, first incision, manipulations with organs, suture of the surgi- cal wound and tracheal extubation constitute the so-called surgical trauma and represent a source 
of very strong painful stimuli. ${ }^{1}$ As a consequence, the activation of the sympatho-adrenal response occurs, resulting in hypertension, tachycardia, arrhythmia, lacrimation, diaphoresis and twitches of skeletal muscles. ${ }^{2}$ These phenomena are especially dangerous in patients with serious cardiovascular diseases. ${ }^{3}$

The concept of general balanced anaesthesia was developed in order to suppress painful stimuli and ensure best operating conditions, however avoiding use of large doses of intravenous or high concentrations of inhalation anaesthetics and high doses of opioid analgesics to avoid the depression of cardiovascular system, delayed postoperative recovery and respiratory depression. ${ }^{4}$ Adjuvant therapy such as short-acting opioid analgesics, local anaesthetics, $\alpha_{2}$-adrenergic receptor agonists, regional neural blocks and $\beta$-adrenergic receptor antagonists have been tried as supplements to the usual technique of general balanced anaesthesia. ${ }^{5}$

Esmolol is a hydrosoluble, selective $\beta_{1}$-adrenergic receptor antagonists. It has a unique pharmacokinetics, since it is metabolised by the esterase located in the cytosol of human erythrocytes. ${ }^{6}$ It is therefore administered exclusively intravenously (iv), in the form of boluses or infusion, with elimination half-time $\left(t_{1 / 2}\right)$ of 10-12 min., 8 This short kinetics is responsible for the titratability of esmolol boluses and infusion when administered to treat episodes of hypertension and tachycardia in various indications, including those arising from perioperative painful stimuli. ${ }^{9,}{ }^{10}$ All these properties make esmolol a logical choice of supplement to the concept of the general balanced anaesthesia. ${ }^{11-13}$

The aim of this clinical trial was to investigate the effect of esmolol on cardiovascular parameters and quality of anaesthesia in patients scheduled for elective plastic surgery.

\section{Methods}

This clinical trial was performed at the Military Medical Academy and approved by the local Ethics Committee. A total of 30 American Society of Anesthesiologists (ASA) class I or II patients aged 18 or above, scheduled for elective plastic surgery were randomly divided into two equal groups - Control and Esmolol. Patients from the
Esmolol group received esmolol solution in glucose $5 \%$, as an iv infusion. Its rate was $0.3 \mathrm{mg} /$ $\mathrm{kg} / \mathrm{min}$ during the first $5 \mathrm{~min}$ and $0.1 \mathrm{mg} / \mathrm{kg} / \mathrm{min}$ thereafter. This maintenance dose was chosen based on the finding that esmolol, when infused at rates up to $0.15 \mathrm{mg} / \mathrm{kg} / \mathrm{min}$, was practically hypotension-free. ${ }^{14}$ Patients from the Control group received the same volume and rate of the plain glucose $5 \%$ solution iv.

All patients received anaesthesia according to the same protocol. They were premedicated 30$45 \mathrm{~min}$ before anaesthesia with diazepam $10 \mathrm{mg}$ intramuscularly (im). Induction to anaesthesia was performed by injecting thiopental sodium $3-5 \mathrm{mg} / \mathrm{kg}$ iv and fentanyl $1.5 \mu \mathrm{g} / \mathrm{kg}$ iv. Neuromuscular blockade was assured by injecting an iv bolus of pancuronium bromide $0.07 \mathrm{mg} / \mathrm{kg}$. The desired level of neuromuscular blockade was maintained by incremental boluses of $0.01 \mathrm{mg} /$ $\mathrm{kg}$. Mixture of oxygen and nitrous oxide $\left(\mathrm{O}_{2} / \mathrm{N}_{2} \mathrm{O}\right.$ $2: 1$ ) was used for maintenance of general anaesthesia.

According to the study protocol, every episode of increase of systolic and diastolic blood pressure or heart rate by more than $20 \%$ of its pre-induction (baseline) value was treated with fentanyl $1.5 \mu \mathrm{g} / \mathrm{kg}$ alone or in combination with droperidol 1:50 $\left(\right.$ Thalamonal $^{\circledR}$ ). After the end of operation, atropine $0.5 \mathrm{mg}$ iv bolus was injected and neostigmine $1.5 \mathrm{mg}$ iv was used for decurarisation. Atropine $0.5 \mathrm{mg}$ iv was used during the operation to treat episodes of bradycardia. It was defined as a decrease of heart rate below 60 beats $/ \mathrm{min}_{15}$ or by more than $20 \%$ of the baseline values.

Systolic and diastolic blood pressure and heart rate were registered in the following phases of anaesthesia and operation: (1) immediately prior to the induction (baseline value), (2) induction to anaesthesia, (3) tracheal intubation, (4) first skin incision, (5) surgical manipulation with organs, (6) suture of the surgical wound and (7) tracheal extubation. In addition to it, total consumption of fentanyl, droperidol, atropine and pancuronium was registered. Quality of the post-anaesthesia recovery was evaluated based on the registration of times needed to regain ability to open eyes on command, to open eyes spontaneously and to regain full orientation. Overall assessment of the quality of anaesthesia was performed by the experienced anaesthesiologist, with the scale: 1 poor, 2 - good and 3 - excellent. 
Statistical analysis was performed by using parametric or non/parametric tests, depending on the nature of the parameters observed and the normality of their distribution. Software IBM SPSS 18.0 was used for these analyses.

\section{Results}

There were no significant differences between the Control and Esmolol groups of patients regarding their age, weight, gender ratio and the baseline values of the cardiovascular parameters (Table 1).

Table 1: Demographic data and preinduction (baseline) values of cardiovascular parameters in patients undergoing elective plastic surgery under general balanced anaesthesia

\begin{tabular}{lccc}
\hline Parameter (unit) & $\begin{array}{c}\text { Control } \\
\text { (mean } \pm \text { SEM) }\end{array}$ & $\begin{array}{c}\text { Esmolol } \\
\text { (mean } \pm \text { SEM) }\end{array}$ & $\begin{array}{c}\text { Statistical } \\
\text { significance }\end{array}$ \\
\hline Age (years) & $41.33 \pm 5.33$ & $37.33 \pm 7.57$ & n.s. \\
\hline Body weight $(\mathrm{kg})$ & $75.67 \pm 8.29$ & $74.00 \pm 6.66$ & n.s. \\
\hdashline $\begin{array}{l}\text { Gender } \\
\text { (male/female) }\end{array}$ & $8 / 7$ & $6 / 9$ & n.s. \\
\hline $\begin{array}{l}\text { Systolic } \\
\text { blood pressure }\end{array}$ & $125.00 \pm 10.41$ & $131.67 \pm 6.01$ & n.s. \\
\hline $\begin{array}{l}\text { Diastolic } \\
\text { blood pressure }\end{array}$ & $81.67 \pm 4.41$ & $88.33 \pm 13.02$ & n.s. \\
\hline $\begin{array}{l}\text { Heart rate } \\
\text { (beats per min) }\end{array}$ & $76.76 \pm 10.14$ & $80.00 \pm 11.55$ & n.s. \\
\hline SEM - standard error on the mean; n.s. - not significant &
\end{tabular}

Figure 1 contains data on the values of systolic blood pressure in the critical phases of anaesthesia and operation, expressed as percentages of their baseline values. In both Control and Esmolol group induction to anaesthesia resulted in decrease in systolic blood pressure, which continued well into the operation. When comparing the values in the two groups in all the critical phases of anaesthesia and operation, it was evident that they tended to be lower in the Esmolol group and this difference reached statistical significance at intubation, first skin incision, suture of the surgical wound and extubation.

Similar results were registered with diastolic blood pressure (Figure 2). Esmolol values of diastolic blood pressure were significantly lower in all critical phases of anaesthesia and operation, except during the first incision.

Results for heart rate values are contained in Figure 3. While the values of the systolic in diastolic blood pressure in the Control group were during most phases of anaesthesia and operation below their baseline values, the Control group values of heart rate were constantly above the baseline ones. At the same time, in the Esmolol group sig-

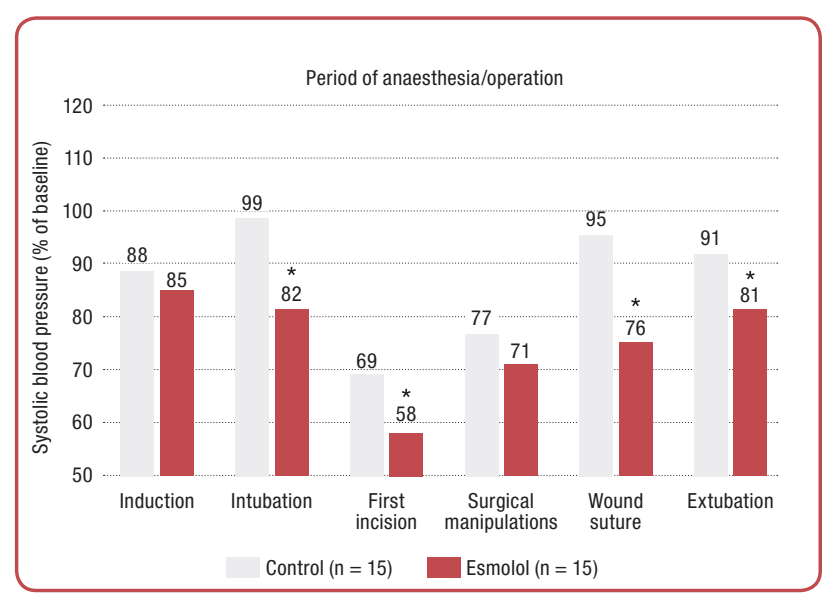

Figure 1: Effect of esmolol on systolic blood pressure in patients undergoing elective plastic surgery under general balanced anaesthesia

${ }^{*} p<0.05$ versus Control

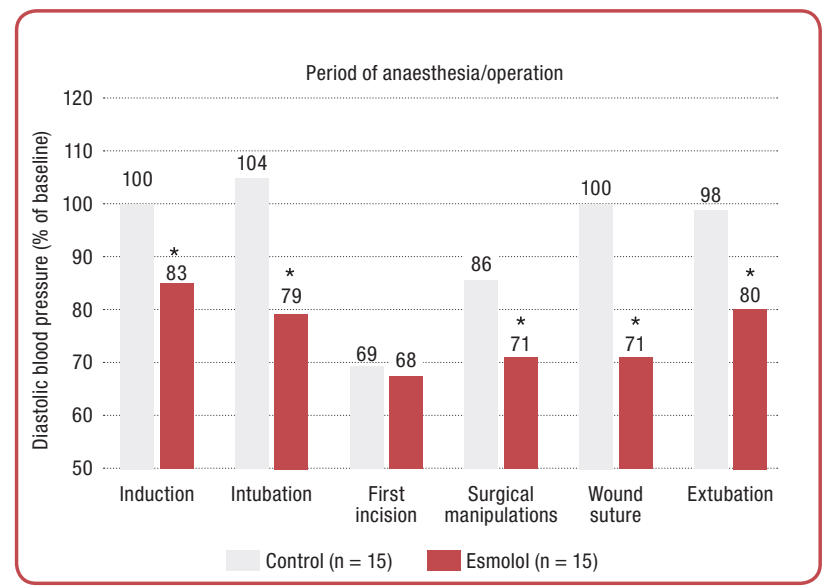

Figure 2: Effect of esmolol on diastolic blood pressure in patients undergoing elective plastic surgery under general balanced anaesthesia

${ }^{*} p<0.05$ versus Control

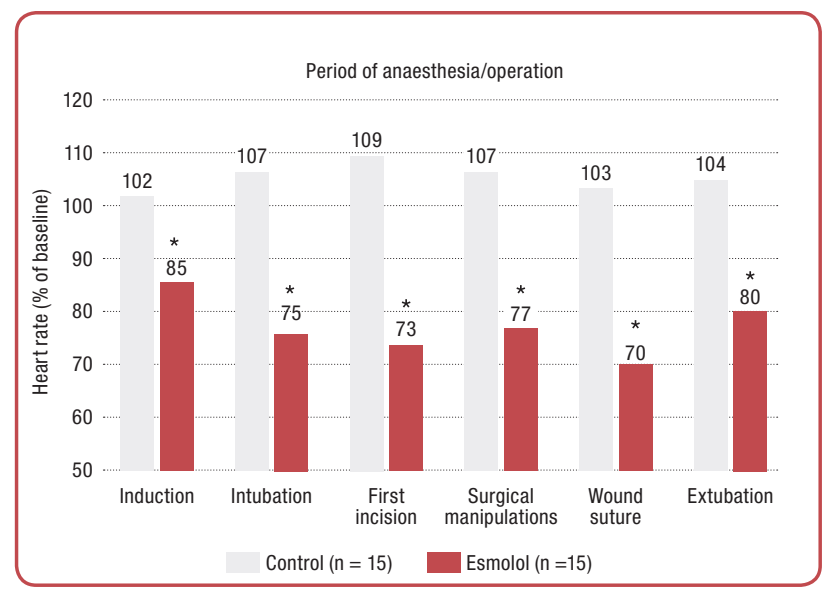

Figure 3: Effect of esmolol on heart rate in patients undergoing plastic surgery under general balanced anaesthesia ${ }^{\star} p<0.05$ versus Control 
nificantly lower heart rate values, ranging 70-85 \% of baseline, were registered.

Table 2 contains data on the total drug consumption. Only atropine was used in a similar dosage in both groups, while in the Esmolol group a significantly lower consumption of fentanyl, droperidol and pancuronium was registered.

Table 2: Consumption of drugs in patients undergoing elective plastic surgery under general balanced anaesthesia

\begin{tabular}{lccc}
\hline Parameter (unit) & $\begin{array}{c}\text { Control } \\
\text { (mean } \pm \text { SEM) }\end{array}$ & $\begin{array}{c}\text { Esmolol } \\
\text { (mean } \pm \text { SEM) }\end{array}$ & $\begin{array}{c}\text { Statistical } \\
\text { significance }\end{array}$ \\
\hline Fentanyl $(\mathrm{mg})$ & $0.38 \pm 0.04$ & $0.13 \pm 0.03$ & $\mathrm{p}<0.05$ \\
\hline Droperidol $(\mathrm{mg})$ & $6.67 \pm 1.67$ & $0.83 \pm 0.83$ & $\mathrm{p}<0.05$ \\
\hline Atropine $(\mathrm{mg})$ & $1.00 \pm 0.29$ & $1.03 \pm 0.09$ & $\mathrm{n} . \mathrm{S}$. \\
\hline Pancuronium $(\mathrm{mg})$ & $14.00 \pm 3.06$ & $3.67 \pm 0.88$ & $\mathrm{p}<0.05$ \\
\hline \multicolumn{4}{l}{ SEM - tandard error on the mean; $n$ n.s. - not significant } \\
\end{tabular}

Table 3: Speed and quality of postoperative recovery in patients undergoing elective plastic surgery under general balanced anaesthesia

\begin{tabular}{|c|c|c|c|}
\hline Parameter (unit) & $\begin{array}{c}\text { Control } \\
\text { (mean } \pm \text { SEM) }\end{array}$ & $\begin{array}{c}\text { Esmolol } \\
\text { (mean } \pm \text { SEM) }\end{array}$ & $\begin{array}{l}\text { Statistical } \\
\text { significance }\end{array}$ \\
\hline $\begin{array}{l}\text { Duration of } \\
\text { anaesthesia (min) }\end{array}$ & $131.67 \pm 15.90$ & $123.00 \pm 33.21$ & n.s. \\
\hline $\begin{array}{l}\text { Opening of eyes on } \\
\text { command (min) }\end{array}$ & $11.67 \pm 1.67$ & $2.67 \pm 1.20$ & $p<0.05$ \\
\hline $\begin{array}{l}\text { Spontaneous open- } \\
\text { ing of eyes (min) }\end{array}$ & $16.67 \pm 4.41$ & $4.50 \pm 1.61$ & n.s. \\
\hline $\begin{array}{l}\text { Regaining of full } \\
\text { orientation (min) }\end{array}$ & $25.00 \pm 2.89$ & $7.33 \pm 1.76$ & $p<0.01$ \\
\hline $\begin{array}{l}\text { Extubation possible } \\
\text { (\% of patients) }\end{array}$ & 100 & 100 & n.s. \\
\hline $\begin{array}{l}\text { Evaluation of quality } \\
\text { of anaesthesia* }\end{array}$ & $2.00 \pm 0.00$ & $2.67 \pm 0.33$ & n.s. \\
\hline
\end{tabular}

Although the duration of anaesthesia and operation were similar in both groups, all the times registered - time until regaining ability to open eyes on command, time until regaining ability to open eyes spontaneously and time until regaining full orientation - were significantly shorter in the Esmolol group.

\section{Discussion}

The obtained results are generally in accordance with some other reports. Esmolol proved to be very efficacious in antagonising haemodynamic changes that accompany laryngoscopy and tracheal intubation. ${ }^{10,16-19}$ Like in the present study, esmolol prevented increases in blood pressure and heart rate during the phase of tracheal extubation. ${ }^{20-22}$ Esmolol also assured a more stable haemodynamics during the non-cardiac ${ }^{23-25}$ and cardiac surgery. ${ }^{26,27}$

Esmolol-induced continuous $\beta$-adrenergic receptor blockade leads to a more sparing use of opioid analgesics, which was demonstrated in the present study and other clinical trials alike. ${ }^{28-30}$ In the current study, a very significant sparing of fentanyl and droperidol were registered.

As a consequence, the patients infused with esmolol had much faster and smoother emergence from anaesthesia than those ones in whom the increases in blood pressure and heart rate were treated with incremental doses of opioid analgesics. $^{31,32}$ The quality of this recovery includes the postoperative nausea and vomiting - a very frequent consequences of opioid administration. ${ }^{32}$ Rarely, opposite results were published - in patients undergoing gynaecologic laparoscopic surgery esmolol did not assure better recovery from anaesthesia, as compared with the saline infusion. ${ }^{33}$ When compared with lidocaine bolus and infusion, esmolol nevertheless also assured better recovery from anaesthesia. ${ }^{34}$

There are some reports that esmolol, similarly like local anaesthetic lidocaine, decreases pain and withdrawal movements after the administration of non-depolarising neuromuscular relaxant rocuronium, via yet unclear mechanisms. ${ }^{35,36}$ It is possible that such mechanisms are responsible for the decreased consumption of pancuronium noted in the present study.

\section{Conclusion}

Esmolol acts as a useful supplement to the other components of the general balanced anaesthesia technique. It blunted the cardiovascular responses to nociceptive stimuli during the critical phases of anaesthesia and operation in patients undergoing elective plastic surgery, assured less consumption of fentanyl, droperidol and pancuronium, leading to faster and smoother emergence from anaesthesia. 


\section{Acknowledgements}

None.

\section{Conflict of interest}

None.

\section{References}

1. Priebe HJ. Pharmacological modification of the perioperative stress response in noncardiac surgery. Best Pract Res Clin Anaesthesiol 2016 Jun;30(2):171-89.

2. Ahonen J, Jokela R, Uutela K, Huiku M. Surgical stress indeks reflects surgical stress in gynaecological laparoscopic day-case surgery. Br J Anaesth 2007;98(4):45661.

3. Teong CY, Huang CC, Sun FJ. The haemodynamic response to endotracheal intubation at different time of fentanyl given during induction: a randomised controlled trial. Sci Rep 2020 Jun 1;10(1):8829. doi: 10.1038/ s41598-020-65711-9.

4. Moon Y, Hwang WJ, Koh HJ, Min JY, Lee J. The sparing effect of low-dose esmolol on sevoflurane during laparoscopic gynaecological surgery. J Int Med Res 2011;39(5):1861-9.

5. Bugada D, Lorini LF, Lavand'homme P. Opioid free anesthesia: evidence for short and long-term outcome. Minerva Anestesiol $2021 \mathrm{Feb}$;87(2):230-7.

6. Quon CY, Mai K, Patil G, Stampfli HF. Species differences in the stereoselective hydrolysis of esmolol by blood esteras- es. Drug Metab Dispos 1988 May;16(3):425-8.

7. Sum CY, Yacobi A, Kartzinel R, Stampfli H, Davis CS, Lai $\mathrm{CM}$. Kinetics of esmolol, an ultrashort-acting beta blocker, and of its major metabolite. Clin Pharmacol Ther 1983 Oct;34(4):427-34.

8. De Bruijn NP, Reves JG, Croughwell N, Clements F, Drissel DA. Pharmacokinetics of esmolol in anesthetized patients receiving chronic beta blocker therapy. Anesthesiology 1987 Mar;66(3):323-6.

9. Johansen JW, Flaishon R, Sebel PS. Esmolol reduces anesthetic requirement for skin incision during propofol/ nitrous oxide/morphine anesthesia. Anesthesiology 1997 Feb;86(2):364-71.

10. Efe EM, Bilgin BA, Alanoglu Z, Akbaba M, Denker C. Comparison of bolus and continuous infusion of esmolol on hemodynamic response to laryngoscopy, endotracheal intubation and sternotomy in coronary artery bypass graft. Rev Bras Anestesiol 2014 Jul-Aug;64(4):247-52.

11. Lončar-Stojiljković D, Dobrić S, Stojiljković MP, Marenović T, Bošković B. [Esmolol as an adjunct to neurosurgical anaesthesia]. Arh Farm 1994;44(1-2):270-1. Serbian.

12. Stojiljković MP, Dobrić $S$, Lončar-Stojiljković $D$, Marenović T, Bošković B. [Use of esmolol in treatment of perioperative tachycardia and hypertension]. Pharmaca Iugoslav 1994;32(1):5-8. Serbian.

13. Lončar-Stojiljković D. Effects of esmolol infusion on cardiovascular parameters and quality of general anaesthesia in younger and older patients. Scr Med 2021 Jun;52(2):109-14.

14. Wiest D. Esmolol. A review of its therapeutic efficacy and pharmacokinetic characteristics. Clin Pharmacokinet 1995 Mar;28(3):190-202.

15. Lin PH, Zhou W, Kougias P, El Sayed HF, Barshes NR, Huyinh TT. Factors associated with hypotension and brady- cardia after carotid angioplasty and stenting. J Vasc Surg 2007 Nov;46(5):846-53.

16. Min JH, Chai HS, Kim YH, Chae YK, Choi SS, Lee A, et al. Attenuation of hemodynamic responses to laryngoscopy and tracheal intubation during rapid sequence induction: remifentanil vs. lidocaine with esmolol. Minerva Anestesiol 2010 Mar;76(3):188-92.

17. Hancı V, Yurtlu S, Karabağ T, Okyay D, Hakimoğlu S, Kayhan G, et al. Effects of esmolol, lidocaine and fentanyl on $\mathrm{P}$ wave dispersion, QT, QTc intervals and hemodynamic responses to endotracheal intubation during propofol induction: a comparative study. Braz J Anesthesiol 2013 May-Jun;63(3):235-44.

18. Singh D, Jagannath S, Priye S, Mudassar AS. The comparison of dexmedetomidine, esmolol, and combination of dexmedetomidine with esmolol for attenuation of sympathomimetic response to laryngoscopy and intubation in patients undergoing coronary artery bypass grafting. Ann Card Anaesth 2019 Oct-Dec;22(4):353-7.

19. Kang JK, Yoo SH, Chung JH, Kim NS, Jung HS, Seo YH, Chun HR, Gong HY, Son HD, Kim AJ. Dosing study of esmolol for reducing hemodynamic changes during lightwand intubation. Anesth Pain Med (Seoul) 2020 Oct 30;15(4):41723.

20. Hosseinzadeh H, Eidy M, Ghaffarlou M, Ghabili K, Golzari SE. Esmolol: a unique Beta-blocker in maintaining cardiovascular stability following neurosurgical procedures. Adv Pharm Bull 2012;2(2):249-52.

21. Alkaya MA, Saraçoğlu KT, Pehlivan G, Eti Z, Göğüş FY. Effects of esmolol on the prevention of haemodynamic responses to tracheal extubation after craniotomy operations. Turk J Anaesthesiol Reanim 2014 Apr;42(2):86-90.

22. Dogan SD, Ustun FE, Sener EB, Koksal E, Ustun YB, Kaya C, Ozkan F. Effects of lidocaine and esmolol infusions on hemodynamic changes, analgesic requirement, and recovery in laparoscopic cholecystectomy operations. Braz J Anesthesiol 2016 Mar-Apr;66(2):145-50.

23. Capuzzo M, Verri M, Alvisi R. Hemodynamic responses to laryngoscopy and intubation: etiological or symptomatic prevention? Minerva Anestesiol 2010 Mar;76(3):173-4.

24. Guney A, Kaya FN, Yavascaoglu B, Gurbet A, Selmi NH, Kaya S, et al. Comparison of esmolol to nitroglycerine in controlling hypotension during nasal surgery. Eurasian J Med 2012 Aug;44(2):99-105.

25. Bajracharya JL, Subedi A, Pokharel K, Bhattarai B. The effect of intraoperative lidocaine versus esmolol infusion on postoperative analgesia in laparoscopic cholecystectomy: a randomized clinical trial. BMC Anesthesiol 2019;19:198. doi: 10.1186/s12871-019-0874-8.

26. Girard D, Shulman BJ, Thys DM, Mindich BP, Mikula SK, Kaplan JA. The safety and efficacy of esmolol during myocardial revascularization. Anesthesiology 1986 Aug;65(2):157-64.

27. Efe EM, Bilgin BA, Alanoglu Z, Akbaba M, Denker C. Comparison of bolus and continuous infusion of esmolol on 
hemodynamic response to laryngoscopy, endotracheal intubation and sternotomy in coronary artery bypass graft. Rev Bras Anestesiol 2014 Jul-Aug;64(4):247-52.

28. Lee MH, Chung MH, Han CS, Lee JH, Choi YR, Choi EM, Lim HK, Cha YD. Comparison of effects of intraoperative esmolol and ketamine infusion on acute postoperative pain after remifentanil-based anesthesia in patients undergoing laparoscopic cholecystectomy. Korean J Anesthesiol 2014 Mar;66(3):222-9.

29. Morais VBD, Sakata RK, Huang APS, Ferraro LHDC. Randomized, double-blind, placebo-controlled study of the analgesic effect of intraoperative esmolol for laparoscopic gastroplasty. Acta Cir Bras 2020 Jun 5;35(4):e202000408. doi: 10.1590/s0102-865020200040000008.

30. Mendonça FT, Tramontini AJ, Miake HI, Seixas LF, de Carvalho LSF, Sposito AC. Intra-operative esmolol and pain following mastectomy: A randomised clinical trial. Eur J Anaesthesiol 2021 Jul 1;38(7):735-743.

31. Park SH, Do SH, Shin HY, Jeon YT, Hwang JW, Han SH. Nicardipine is more effective than esmolol at preventing blood pressure increases during emergence from total intravenous anesthesia. Korean J Anesthesiol 2009 Nov;57(5):597-603.
32. Lee SJ, Lee JN. The effect of perioperative esmolol infusion on the postoperative nausea, vomiting and pain after laparoscopic appendectomy. Korean J Anesthesiol 2010 Sep;59(3):179-84.

33. De Oliveira GS Jr, Kendall MC, McCarthy RJ. Esmolol does not improve quality of postsurgical recovery after ambulatory hysteroscopy: A prospective, randomized, double-blinded, placebo-controlled, clinical trial. Medicine (Baltimore) 2018 Oct;97(41):e12647. doi: 10.1097/ MD.0000000000012647.

34. Yavascaoglu B, Kaya FN, Ozcan B. Esmolol pretreatment reduces the frequency and severity of pain on injection of rocuronium. J Clin Anesth 2007 Sep;19(6):413-7.

35. Bajracharya JL, Subedi A, Pokharel K, Bhattarai B. The effect of intraoperative lidocaine versus esmolol infusion on postoperative analgesia in laparoscopic cholecystectomy: a randomized clinical trial. BMC Anesthesiol 2019 Nov 4;19(1):198. doi: 10.1186/s12871-019-0874-8.

36. Ergil J, Kavak Akelma F, Özkan D, Bumin Aydin G, Gürel A, Akinci M. Effects of pretreatment with esmolol and lidocaine on injection pain and rocuronium-induced withdrawal response. Turk J Med Sci 2015;45(4):959-63. 